Nevertheless they generally reported less chronic pain after treatment with acyclovir, ${ }^{810}$ and this is consistent with other uncontrolled data. ${ }^{+11}$

On balance, therefore, it seems more reasonable to conclude that acyclovir can reduce, though not completely prevent, post-herpetic neuralgia.

R J CROOKS

A R BELL A P FIDDIAN

Department of Clinical Virology and Vaccines, Wellcome Research Laboratories, Beckenham, Kent BR3 3BS

1 Jolleys JV. Treatment of shingles and post-herpetic neuralgia BrMed f 1989;298:1537-8. (10 June.)

McKendrick MW, McGill JI, Wood MJ. Lack of effect of acyclovir on postherpetic neuralgia. Br Med f 1989;298:431. Wood MJ, Ogan PH, McKendrick MW, Card CD, McGill JI Wood EM. Efficacy of oral acyclovir treatment of acute herpes zoster. Am f Med 1988;85:79-83.

4 Klenerman P, Peto TEA, Luzzi GA, Juel-Jensen BE. Antiviral treatment and postherpetic neuralgia. $\mathrm{Br}$ Med $\mathcal{F}$ 1989;298:

Esmann V, Geil JP, Kroon S, et al. Prednisolone does not prevent post herpetic neuralgia. Lancet 1987;ii:126-9.

Huff JC, Bean B, Balfour HH, et al. Therapy of herpes zoster with oral acyclovir. Am $\mathcal{J}$ Med 1988;85:84-9.

With olal acyclovir. Am Jed 1988,85:84-9. Morton $\mathrm{P}$, Thomson AN. Oral acyclovir in the treatment of herpes zoster in general practice. NZ Med f 1989;102:93-5.

Bean B, Braun C, Balfour HH. Acyclovir therapy for acute herpes zoster. Lancet 1982;ii:118-21.

McGill J, MacDonald DR, Fall C, McKendrick GDW, Copplestone $A$. Intravenous acyclovir in acute herpes zoster infection. F Infect 1983;6:157-61.

10 Juel-Jensen BE, Khan JA, Pasvol G. High-dose intravenous acyclovir in the treatment of zoster: a double blind placebo controlled trial. F Infect 1983;6(suppl 1):31-6.

11 Bannister P, Crosse B. Severe herpes zoster infection in the United Kingdom: experience in a regional infectious diseases unit. F $R$ Soc Med 1989;82:145-6.

AUTHOR'S REPLY - In the light of current research, published data do not support the conclusion that acyclovir can reduce, though not completely prevent, post-herpetic neuralgia. As pointed out, the references given to support the lack of effect of acyclovir on the incidence of post-herpetic neuralgia appear to be a dual publication,,$^{12}$ bu other double blind, controlled trials of oral acyclovir for herpes zoster in normal subjects also reported no reduction in the occurrence of postherpetic neuralgia in the treated group. ${ }^{34}$

Several randomised, placebo controlled, double blind trials of intravenous acyclovir in immunocompetent patients with herpes zoster have been published, ${ }^{5-7}$ two of which showed that pain was reduced in the treatment group both in the acute phase and at follow up when compared with the placebo group, but the difference was not statistically significant. ${ }^{56}$ Bean $e t$ al found that intravenous acyclovir reduced pain in the acute phase but did not seem to affect the development of post-herpetic neuralgia. ${ }^{7}$

An apparent reduction in post-herpetic neuralgia has been reported from a review of patients treated early in the disease with intravenous antiviral agents, either vidarabine or acyclovir. Bannister and Crosse reviewed cases of severe herpes zoster admitted to a regional infectious diseases unit over a three year period and reported a reduction in complication rate, including postherpetic neuralgia, in those who received intravenous acyclovir. ${ }^{9}$ This was not a controlled trial, and even so a higher than predicted level of neuralgia was reported, possibly reflecting the severity of the cases referred to the unit.

Esmann and colleagues showed that the combination of steroid treatment and oral acyclovir was no more effective than treatment with acyclovir alone. ${ }^{10}$ As both groups experienced a higher than predicted rate of neuralgia it can be deduced that acyclovir neither prevented nor reduced postherpetic neuralgia in this study. The two placebo controlled studies of oral acyclovir report that although post-zoster pain in the treated group is reduced at three months, by six months this advantage can no longer be shown. ${ }^{112}$

Further prospective controlled trials on large populations of patients with herpes zoster are needed to determine the true efficacy of both the intravenous and oral preparations of acyclovir on the course of post-herpetic neuralgia. Research evidence is contradictory and whether acyclovir can reduce or prevent post-herpetic neuralgia remains unproved. This conclusion is borne out by the company's promotional literature.

General Practice Unit,

JACQUELINE V JOLLEYS

Department of Community Medicine,

Leicester Royal Infirmary,

Leicester LE1 5WW

1 McKendrick MW, McGill JI, Wood MJ. Lack of effect of acyclovir on post-herpetic neuralgia. $\mathrm{Br}$ Med $\mathrm{f}$ 1989;298:43 2 Wood MJ, Ogan PH, McKendrick MW, Care CD, McGill JI, Webb EM. Efficacy of oral acyclovir treatment of acut herpes zoster. Am F Med 1988;85:79-83

3 Wassilew SW, Reiminger S, Nasemann T, Jones D. Ora acyclovir for herpes zoster: a double-blind controlled trial in normal subjects. Br F Dermatol 1987;117:495-501.

4 Cobo LM, Foulks GN, Liesegang T, et al. Oral acyclovir in the treatment of acute herpes zoster ophthalmicus. Ophthalmology 1986;93:763-70.

5 McGill J, MacDonald DR, Fall C, McKendrick GDW, Copplestone $A$. Intravenous acyclovir in acute herpes zoster infecstone A. Intravenous acyclo
tion. I Infect 1983;6:157-61.

6 Juel-Jensen BE, Khan JA, Pasvol G. High-dose intravenou acyclovir in the treatment of zoster: a double blind placebo controlled trial. F Infect 1983;6(suppl 1):31-6.

7 Bean B, Braun C, Balfour HH. Acyclovir therapy for acute herpes zoster. Lancet 1982;ii:118-21.

8 Klenerman P, Peto TEA, Luzzi GA, Juel-Jensen BE. Antivira treatment and post-herpetic neuralgia. Br Med $\mathcal{J}$ 1989;298: 832.

9 Bannister P, Crosse B. Severe herpes zoster infection in the United Kingdom: experience of a regional infectious diseas unit. F $R$ Soc Med 1989;82:145-6.

10 Esmann V, Geil JP, Kroon S, et al. Prednisolone does not prevent postherpetic neuralgia. Lancet 1987;ii:126-9.

11 Huff JC, Bean B, Balfour HH, et al. Therapy of herpes zoster with oral acyclovir. Am f Med 1988;85:84-9.

12 Morton P, Thomson AN. Oral acyclovir in the treatment of herpes zoster in general practice. NZ Med f 1989;102:93-5.

SIR, - In Dr J Jolleys's editorial on the treatmen of shingles and post-herpetic neuralgia treatment is said to relieve shingles but not to prevent postherpetic neuralgia.' Dr Jolleys mentions that oral acyclovir given early in the illness in a dosage of $800 \mathrm{mg}$ five times daily for seven days has been found not to reduce the incidence of post-herpetic neuralgia. ${ }^{23}$ In a recent multicentre randomised placebo controlled trial, however, oral acyclovi given in a dosage of $800 \mathrm{mg}$ five times daily for 10 days within 72 hours of the onset of the rash resulted in a statistically significant reduction in chronic persistent pain during the six months after treatment. ${ }^{+}$This suggests that further studies are required to evaluate the role of longer courses of oral acyclovir in preventing post-herpetic neuralgia.

PAMELA TODD

Department of Dermatology JOHN THOMSON

Royal Infirmary

Glasgow G4 0SF

1 Jolleys JV. Treatment of shingles and post-herpetic neuralgia Br.Med F 1989;298:1537-8. (10 June.)

McKendrick MW, McGill JI, Wood MW'. Lack of effect of acyclovir on post-herpetic neuralgia. Br Med f 1989;298:431.

Wood MJ, Ogan PH, McKendrick MW, Care CD, McGill Jl, Webb EM. Efficacy of oral acyclovir in the treatment of acute herpes zoster. Am J Med 1988;85:79-83.

4 Huff JC. Oral acyclovir therapy of acute herpes zoster: a multicentre study. Research and Clinical Forums 1987;9:37-43.

\section{The computer will see you now}

SIR, - The otherwise admirable leading article by Dr A J Pelosi and G Lewis repeats the notion that socially undesirable responses are more likely to be divulged to a computer than to a human being. The evidence for this is from studies examining the agreement of a computer with clinicians. Where computers elicit more socially undesirable responses than clinicians a more parsimonious explanation is simply that there is disagreement. The authors quote one reference in which computer elicited reports of a higher alcohol consumption than did clinicians, ${ }^{2}$ but the four studies in this area show no consistent trend Furthermore, the study quoted ${ }^{3}$ found no difference between computer and clinicians in rates of disabilities related to alcohol, which are more personally embarrassing than level of alcohol ntake.

Where computers may score over humans is in unfailingly covering every designated domain, but then computer interviews take longer. ${ }^{3}$

King's College Hospital

M W BERNADT

London SE5 9RS

1 Pelosi AJ, Lewis G. The computer will see you now. Br Med 7 1989;299:138-9. (15 July.)

Lucas RW, Mullin PJ, Luna CBX, McInroy DC. Psychiatrists and a computer as interrogators of patients with alcoholrelated illnesses: a comparison. Br f Psychiatry 1977;131:160-7. 3 Bernadt MW, Daniels OJ, Blizard RA, Murray RM. Can a computer reliably elicit an alcohol history? $\mathrm{Br} f$ Addict 1989;84:405-11.

\section{Drug Points}

\section{Acute confusional state with postoperative intravenous cefazolin}

Drs Anthony M Herd and Colin A Ross (Department of Psychiatry) and Mr SAMIR K BhatTACHARYA (Department of Surgery, St Boniface General Hospital, Winnipeg, Manitoba, Canada R2H 2A6) write: We describe a case of postoperative delerium associated with intravenous cefazolin.

A 66 year man with a history of coronary artery disease and bypass surgery underwent an uncomplicated second four vessel bypass operation. $\mathrm{He}$ weathered the usual postoperative course of arrhythmias and haemodynamic derangements, which responded to normal doses of vasopressors and antiarrhythmic agents. There were no prolonged periods of hypotension or hypoxaemia. He received intravenous cefazolin $1 \mathrm{~g}$ every eight hours for eight doses prophylactically with morphine and diazepam as required. He was extubated on the second postoperative day.

From the second day he had a fluctuating level of alertness and orientation and disturbance of the sleep-wake cycle. He was agitated and combative and spoke and behaved as if hallucinating. Multiple investigations, including computed tomography, failed to disclose any cause for this acute confusional state. On the fifth day he developed fever up to $40.0^{\circ} \mathrm{C}$ rectally. Again numerous investigations, including lumbar puncture, failed to show a definitive focus. Intravenous cefazolin, 2 g every eight hours, was started for the presumed foci of lung or wound infection and his fever disappeared within 60 hours.

The mental changes persisted unabated and on the 17 th day the psychiatric service was consulted. There was no personal or family history of psychiatric disorder, no history of substance abuse, and no premorbid changes in cognition or personality. There was no history of delerium after the previous double bypass surgery and no history of drug reactions. His medications at the time were cefazolin $2 \mathrm{~g}$ every eight hours, digoxin $0.25 \mathrm{mg}$ once a day (level therapeutic), mexilitene $100 \mathrm{mg}$ three times a day, enteric coated aspirin $325 \mathrm{mg}$ twice a day, dipyridamole $75 \mathrm{mg}$ twice a day, and haloperidol $1 \mathrm{mg}$ as required. The aspirin and dipyridamole had been started on the second postoperative day, while the digoxin and mexilitene had been started on the fifth and seventh days respectively. The haloperidol was used infrequently as a single nightly dose. On the Folstein mini 
mental state examination he scored 17 out of a possible 30.

Postoperative delerium was diagnosed and the cefazolin discontinued; within 24 hours his mental state had improved sufficiently to allow discharge. All other medications were continued, save for the haloperidol, which was no longer required Psychiatric follow up at one week confirmed complete resolution of his delerium.

Published reports cite neuropsychiatric symptoms developing with several of the cephalosporins - notably, cefuroxime and cephalexin,' cephalothin and cephaloridine, ${ }^{12}$ and cephacetrile, ceftazidime, and cefazolin. ${ }^{3}$ The health protection branch of Health and Welfare Canada, as well as one of the Canadian manufacturers of cefazolin, each lists two putative cases, though the evidence is anecdotal only (personal communication). This patient presented with classical changes in consciousness and mentation of a delerium or acute confusional state. While postcardiotomy delerium occurs in up to $28 \%$ of patients ${ }^{4}$ it tends to be brief and responds well to low dose haloperidol and reorientation in a quiet environment. As other organic causes had been adequately ruled out and there was no evidence of a functional aetiology we thought an adverse drug reaction was the most likely cause and cefazolin the most likely offending agent. Though it had been interrupted earlier in this man's postoperative course, it was the only agent present from the onset of his confusion and thus was at least a potentiating, if not an initiating, factor. Within 24 hours of the drug being stopped his mental state cleared remarkably, consistent with the observation of Vincken.'

Though the incidence of acute confusion with cephalosporins is likely to be small, and in this case the benefits of treating the postoperative fever vastly outweighed the risks, the case reminds us that adverse drug reactions should be high on the list of differential diagnoses in the acutely confused patient.

1 Vincken W. Psychotic reaction with cefuroxime. Lancet 1984 i: 965

Norrby SR. Side effects of cephalosporins. Drugs 1987;34(suppl 2): $105-20$.

3 Geyer J, Hoffler D, Demers HG, Neimeyer R. Cephalosporin induced encephalopathy in uremic patients. Nephron 1988 48:237.

4 Kornfeld DS, Heller SS, Frank KA, Edie RN, Barsa J. Delerium fter coronary artery bypass surgery. I Thorac Cardiovasc Surg 1978;76:93-6.

\section{Arthralgia associated with captopril}

Drs S D H Malnick and A SchatTNer (Department of Medicine C, Kaplan Hospital, 76100 Rehovot, Israel) write: Following the report of pseudopolymyalgia rheumatica associated with enalapril' we report a case of severe polyarthralgia and a false positive Venereal Disease Research Laboratory test result associated with captopril.

A 54 year old man was being treated with atenolol for hypertension, but after showing mildly disturbed lung function he was given captopril instead. Several days after treatment with captopril was started the patient experienced a migratory arthralgia in the metacarpophalangeal joints and wrists. After a month he experienced a severe arthralgia in the left hip, which he noted increased in severity one to two hours after he took the captopril tablets. Physical examination showed a considerable reduction in the mobility of the left hip with no local erythema or heat. A radiograph of the hip was normal. Laboratory investigations showed an erythrocyte sedimentation rate of 30 $\mathrm{mm}$ in the first hour and normal full blood count, glucose and electrolyte concentrations, and liver function values. Serological tests șhowed negative results of Rose-Waaler, latex, and antinuclear factor tests and normal concentrations of complement. A false positive result on the Venereal Disease Research Laboratory test was, however, found. Treatment with captopril was stopped and the patient received diclofenac and subsequently naproxen. Two weeks later he was entirely asymptomatic and the false positive result was no longer present. The patient declined rechallenge with captopril.

There have been reports of a serum sickness like syndrome with arthralgia, rash, and membranous glomerulopathy that resolved in two weeks. Urticaria with arthralgia that resolved on withdrawal of captopril has also been described, ${ }^{34}$ but a false positive Venereal Disease Research Laboratory test result has not been associated with captopril. The mechanism for this effect is unclear, but captopril has a similar structure and metabolite profile to penicillamine.' We suggest that the prevalence of "silent" autoantibodies in the serum of patients receiving captopril should be determined $^{6}$ and that captopril may rarely cause a drug induced autoimmune disorder in susceptible individuals.

1 Leloet X, Moore N, Deshages P. Pseudopolymyalgia rheumatic during treatment with enalapril. Br Med f 1989;298:325.

2 Hoorntie SJ, Ween JJ, Kallenberg CGM, et al. Serum sicknesslike syndrome with membranous glomerulopathy in patient on ike syndrome with membrano

3 Smit AJ, Van der Laan S, DeMonchy J, et al. Cutaneous reactions to captopril-predictive value of skin tests. Clin Allergy 1984;14:413-9.

4 Luderer JR, Lookingbill DP, Schneck DW, et al Captoprilinduced skin reactions. F Clin Pharmacol 1982;22:151-9.

5 Dixon JS, Bird HA, Martin MFR, et al. Biochemical and clinical changes occurring during the treatment of rheumatoid arthritis with novel anti-rheumatoid drugs. Int $\mathcal{f}$ Clin Pharmacol Res 1985;5:25-33.

6 Schattner A. The origin of autoantibodies. Immunol Lett 1987; $14: 143-53$

\section{Early renal artery occlusion after enalapril in atheromatous renal artery stenosis}

Drs J MAIN and R WILKINSON (Renal Unit, Freeman Hospital, Newcastle upon Tyne) write: Reversible renal failure is a well known side effect of angiotensin converting enzyme inhibitors in patients with severe renovascular disease. Renal artery occlusion associated with the use of angiotensin converting enzyme inhibitors has been reported, ${ }^{1.5}$ but we report a further case with important differences from the previous ones.

Over six months difficulty was experienced in controlling the blood pressure of a 71 year old woman who was an ex-smoker. Initial treatment included captopril and was associated with a pronounced fall in blood pressure and a rise in plasma creatinine concentration from 153 to $222 \mu \mathrm{mol} / \mathrm{l}$ over three weeks. Captopril was stopped and creatinine fell gradually to $135 \mu \mathrm{mol} / \mathrm{l}$ in association with loss of blood pressure control. Intravenous urography showed a normal left kidney and a small right kidney with a faint but persistent nephrogram. The patient was treated with various combinations of nifedipine, methyldopa, frusemide, and prazosin, and plasma creatinine fluctuated between 133 and $210 \mu \mathrm{mol} / \mathrm{l}$. After she developed clinical and radiographic features of pulmonary oedema and side effects of higher doses of prazosin and frusemide treatment was replaced by enalapril $2.5 \mathrm{mg}$ daily, increased after three days to $5 \mathrm{mg}$ with the addition of bumetanide $1 \mathrm{mg} /$ day. Six days after starting enalapril the patient became anuric and developed acute pulmonary oedema. She reported no symptoms of hypotension, and the lowest recorded blood pressure after enalapril was started was 140/70 mm Hg. Despite a good symptomatic response to intravenous diamorphine, frusemide, and isosorbide dinitrate she remained anuric over the next 12 hours. A return of symptomatic pulmonary oedema was successfully treated with the removal of 2 litres of fluid in three hours by arteriovenous haemofiltration. Urgent arteriography showed occlusion of the right renal artery and a stenosis of the left renal artery with a distal occluding thrombus. It proved impossible to pass a guidewire through this obstruction despite infusion of streptokinase into the artery. The patient was not fit for surgery, and regular haemodialysis was started. After 10 days she suffered a cardiac arrest and died. Necropsy confirmed the presence of an atheromatous stenosis and recent occlusive thrombus in the left renal artery.

In four reports of six patients developing renal artery occlusion in association with angiotensin converting enzyme inhibitor treatment in native kidneys $^{1+}$ the occlusions were discovered several months after treatment started. In each case there was a non-affected kidney, and the diagnosis was made by arteriography. In the one case with a close temporal association ${ }^{5}$ the renal artery thrombosis was attributed to profound hypotension which developed three hours after the first dose of captopril. The important differences in our case were the close temporal association and the absence of hypotension.

It is, of course, possible that renal artery occlusion after several months' treatment simply represented the natural course of the disease, but the close temporal association in our case makes it more likely that the drug was responsible. Tillman et al have suggested that angiotensin converting enzyme inhibitors should be used for one month before definitive treatment in this group of patients, ${ }^{4}$ so the occurrence of early occlusion is important

We cannot be sure that this patient did not have an unrecorded asymptomatic hypotensive episode, but the development of pulmonary oedema quickly after the onset of apnuria suggests that she was not hypovolaemic at the time of renal artery thrombosis. The ease of removal of 2 litres of fluid by haemofiltration without hypotension supported the absence of hypovolaemia.

In this patient previous exposure to angiotensin converting enzyme inhibitors had produced only modest rise in plasma creatinine concentration. We have found that the effect of angiotensin converting enzyme inhibitors in patients with radiographically severe renal artery stenosis is variable, ranging from undetectable to rapid complete loss of function. In such patients rena function may diminish if blood pressure falls below a certain level, and this may explain the fluctuations in renal function seen in this patient during treatment with other drugs. The possibility of bilateral renal artery stenosis was considered, but we had thought that careful monitoring of creatinine concentrations would be sufficient precaution when enalapril was introduced. If angiotensin converting enzyme inhibitors can produce renal artery occlusion then clearly such an approach is not safe, and these drugs should be avoided in all patients in whom atheromatous renal artery stenosis is likely. This is a sizable group including all hypertensive patients with evidence of vascular disease elsewhere or with any un diagnosed impairment of renal function.

The Committee on Safety of Medicines does not have a distinct category for renal artery occlusion, but the manufacturers are aware of three previous reports with enalapril ( $M$ Walters, Merck, Sharp \& Dohme Ltd, personal communication).$^{2+4}$

1 Hoefnagels WHL, Thien T. Renal artery occlusion in patien with renovascular hypertension treated with captopril. BrMed f 1986;292:24-5.

2 Hartnell GG, Allison DJ. Renal artery occlusion in patients with renovascular hypertension treated with captopril. $\mathrm{Br} \mathrm{Med}$ 1986;292:410

3 Khalife K, Juilliere Y, Zannad F. Stenose bilaterale de l'artere renale. Therapie 1985;40:481.

4 Tillman DM, Malatino LS, Cumming AMM, et al: Enalapril in hypertension with renal artery stenosis: long-term follow-up and effects on renal function. $\mathcal{F}$ Hypertension 1984;2(supp 2):93-100

5 Williams PS, Hendy MS, Ackrill P. Captopril-induced acute renal artery thrombosis and persistent anuria in a patient with cocum Postgrad Med $\mathcal{J} 1984 ; 60: 561-3$. 